\title{
Conversion to drip irrigated agriculture may offset historic anthropogenic and wildfire contributions to sediment production
}

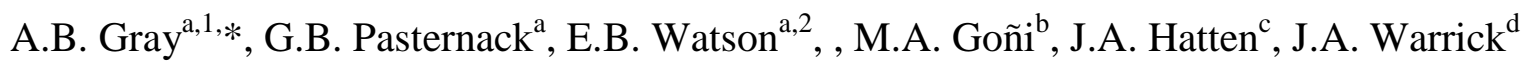

${ }^{a}$ University of California, Davis, One Shields Avenue, Davis, CA 95616, USA

Andrew.gray@ucr.edu, gpast@ucdavis.edu, elizabeth.b.watson@drexel.edu

${ }^{\mathrm{b}}$ Oregon State University, 104 CEOAS Administration Bldg., Corvallis, OR 97331-5503, USA, mgoni@coas.oregonstate.edu

${ }^{\mathrm{c}}$ Oregon State University, College of Forestry, Corvallis, OR 97331-5704, USA jeff.hatten@oregonstate.edu

${ }^{\mathrm{d}}$ United States Geological Survey, 400 Natural Bridges Drive, Santa Cruz, CA 95060, USA jwarrick@usgs.gov

*Corresponding author: Tel.: +1 951-827-6159; Fax: +1 951-827-3993;

E-mail: andrew.gray@ucr.edu.

${ }^{1}$ Current affiliation: University of California, Riverside, Department of Environmental Sciences, 900 University Ave., Riverside, CA 92521, USA

${ }^{2}$ Current affiliation: Academy of Natural Sciences of Drexel University, Department of Biodiversity, Earth and Environmental Science, Philadelphia, PA 19103, USA 


\section{Abstract}

This study is an investigation into the roles of wildfire and changing agricultural practices in controlling the inter-decadal scale trends of suspended sediment production from semi-arid mountainous rivers. In the test case, a decreasing trend in suspended sediment concentrations was found in the lower Salinas River, California between 1967 and 2011. Event to decadal scale patterns in sediment production in the Salinas River have been found to be largely controlled by antecedent hydrologic conditions. Decreasing suspended sediment concentrations over the last 15 years of the record departed from those expected from climatic/hydrologic forcing. Sediment production from the mountainous headwaters of the central California Coast Ranges is known to be dominated by the interaction of wildfire and large rainfall/runoff events, including the Arroyo Seco, a $\sim 700 \mathrm{~km}^{2}$ subbasin of the Salinas River. However, the decreasing trend in Salinas River suspended sediment concentrations run contrary to increases in the watershed's effective burn area over time. The sediment source area of the Salinas River is an order of magnitude larger than that of the Arroyo Seco, and includes a more complicated mosaic of land cover and land use. The departure from hydrologic forcings on suspended sediment concentration patterns was found to coincide with a rapid conversion of irrigation practices from sprinkler and furrow to subsurface drip irrigation. Changes in agricultural operations appear to have decreased sediment supply to the Salinas River over the late $20^{\text {th }}$ to early $21^{\text {st }}$ centuries, obscuring the influence of wildfire on suspended sediment production.

Keywords: Suspended sediment; agriculture; wildfire; non-stationary; human land use; watershed hydrology. 


\section{Introduction}

\subsection{Watershed sediment flux}

Fluvial suspended sediment fluxes from developed watersheds in semi-arid environments are influenced by natural and human induced changes to the land surface that interact with extremely variable climatic regimes. Environmental monitoring and sedimentary records indicate that fluvial sediment flux dynamics often exhibit temporal dependence over event to inter-decadal time scales, particularly in arid to semi-arid climates (Morehead et al., 2003; Walling and Fang, 2003; Syvitski et al., 2005; Gao et al., 2013, Gray et al., 2015b). However, attributing changes in sediment regimes to a discrete cause is often complicated by the overprinting of many external drivers and internal dynamics that affect watershed scale sediment production and transport, which tend to obscure the effects of individual forcing factors (Walling, 1977; Syvitski et al., 2000). Furthermore, factors affecting watershed-scale sediment production operate over a wide range of time scales, with even seemingly discrete events generating legacy effects that may last for years or decades (Warrick et al., 2012; Warrick et al., 2013; Gray et al., 2014). Semi-arid basins in particular have been found to display persistent dependence on climatically driven antecedent basin conditions, such as storm/flood and wildfire histories (Abraham, 1969; Tanji et al., 1980; Lenzi and Marchi, 2000; Lana-Renault et al., 2007; Warrick and Rubin, 2007; López-Tarazón et al., 2011; Gray et al., 2015a). The addition of human influences further complicates sediment flux controls in the highly developed portions of the world that are the most intensively studied (Walling, 2006; Syvitski and Milliman, 2007).

Thus, elucidation of temporal dependence in the suspended sediment dynamics of a highly developed, semi-arid basin is a forensic exercise of implicating and eliminating a host of 
potential controls. For this reason, when discrete controls on sediment dynamics are discovered in a given watershed it is often the result of scenarios where proportionally large areal disturbances have dominated the sediment response of relatively small (area $<1,000 \mathrm{~km}^{2}$ ) watersheds. In this way, wildfire (Florsheim, 1991; Cerdà, 1998; Lavé and Burbank, 2004; Warrick et al., 2012), urbanization (Wolman and Schick, 1967; Trimble, 1997; Warrick and Rubin, 2007), and agriculture (Gao and Pasternack, 2007; Abaci and Papanicolaou, 2009; Estrany et al., 2009; Florsheim et al., 2011) have been found to exert significant control on fluvial sediment flux. However, understanding the fluvial sediment dynamics of most systems over inter-decadal time scales requires the disentanglement of multiple controls, particularly at larger spatial scales.

\subsection{Internal and external controls}

The most important external driver controlling inter-decadal scale sediment flux is regional climate, which interacts with internal factors such as geological substrate and topography to influence internal processes such as geomorphic evolution, soil development, vegetation assemblages, and fire frequency (Syvitski et al., 2000). The interaction of vegetation, topography and interannual to decadal scale climatic expression also largely determines wildfire regimes (Pyne et al., 1996). Sediment flux generally rises after wildfire due to increases in the erodibility of hillslope surfaces through the removal of vegetation and litter layers, destabilization of soil aggregates by organic matter combustion, and increases in soil mantle slides or overland flow due to the development of subsurface and surface soil hydrophobicity, respectively (Debano and Krammes, 1966; Keller et al., 1997; DeBano, 2000; Gabet, 2003). In systems experiencing dry seasons, such as much of the Western U.S., this results in down-slope 
dry-ravel transport through gravity alone (Swanson, 1981; Jackson and Roering, 2009; Lamb et al., 2011; Hubbert et al., 2012). Soil heating can also cause hydrophobicity increases in the soil surface that, along with decreases in interception and evapotranspiration, cause increases in surface runoff during the wet season (Shakesby and Doerr, 2006). Increased surface runoff further exacerbates erosion from the destabilized hillslope. Indeed, the timing of high-intensity precipitation plays a large role in post-fire sediment flux augmentation (Inbar et al., 1998; Warrick et al., 2012; Staley et al.; 2014). Large storms produce precipitation intensities and volumes sufficient to traverse runoff regimes, from sheet flow, to rill and gully erosion, and mass wasting, which can very effectively erode wildfire destabilized hillslopes (Cannon, 2001; Moody et al., 2008). With increasing elapsed time between wildfire and high intensity precipitation events, hillslopes generally re-vegetate, re-stabilize, and yield less sediment for a given precipitation magnitude (Inbar et al., 1998; Cerdà and Lasanta, 2005; Malmon, 2007; Warrick et al., 2012), although decadal scale legacies of individual fires have been reported (Sass et al., 2012).

Humans have caused pre-historic to historic increases in global sediment flux due largely to agriculture and deforestation (Wolman and Shick, 1967; Beschta, 1978; Milliman and Meade, 1983; Pasternack et al., 2001; Piegay et al., 2004; Syvitski et al., 2005; Walling, 2006; Weston 2014). This phenomenon has generally been followed by a rapid decrease in sediment flux during the $20^{\text {th }}$ century, primarily from river impoundment, and to a lesser degree changes in agricultural practices and afforestation (Vorosmarty et al., 2003; Walling, 2006). Changes in agricultural practices over the last century have in many cases led to decreases in off-field sediment transport with the implementation of soil conservation practices, including changes to less erosive irrigation techniques (Carter et al., 1993; Koluvek et al., 1993; Tomer et al., 2010; 
Wilson et al., 2014). Flow regulation (i.e. damming) causes declines in basin scale sediment yield by trapping sediment in reservoirs and altering the natural flow regime, particularly through reduction of peak flood discharge magnitudes (Pasternack et al., 2001; Vorosmarty et al., 2003; Willis and Griggs, 2003; Walling and Fang, 2003; Walling, 2006; Warrick and Rubin, 2007, Estrany et al., 2009). After an initial spike during construction, urbanization can also lead to sediment load decreases with the increase in the cover of impervious surfaces (Wolman, 1967; Wolman and Schick, 1967; Warrick and Rubin, 2007; Minear, 2010). Conversely, extensive urbanization can act to increase sediment yield by altering basin scale precipitation - discharge characteristics (i.e. hydrologic response); for example shortening the time to peak flow, decreasing total flow duration, increasing peak magnitude, and increasing total runoff volume (Espey, 1969; Hollis, 1975; Trimble, 1997; Warrick and Rubin, 2007).

\subsection{Assessment of sediment controls}

Due to the difficulty and expense of collecting samples, fluvial suspended sediment flux is usually estimated on the basis of infrequent sediment monitoring coupled with more frequent or even continuous discharge monitoring (Horowitz, 2003). The most common technique is to compute sediment concentration $\left(C_{S S}\right)$-discharge $(Q)$ rating curves using log-linear regression or non-parametric localized regression methods such as LOESS (Walling, 1977; Walling and Webb, 1988; Tananaev, 2013). Anthropogenic disturbances and wildfire will alter $C_{S S^{-}} Q$ relationships if they result in disproportionate changes in the magnitude and/or timing of the supply of sediment or water relative to one another (Warrick, 2014).

Thus, changes in sediment flux and $C_{S S^{-}} Q$ relationships examined in relation to agriculture and wildfire activity over time can provide insight into these important controls on 
sediment dynamics in highly agricultural, semi-arid basins. Determination of the dominance of a factor potentially controlling sediment production over other factors can be approached through the comparison of the temporal trends of control metrics with the metric describing sediment production. Correlation between control factors and sediment production metrics can then be analyzed and interpreted in light of the expected effects of a given control (i.e. acting to increase or decrease sediment supply).

\subsection{Study objectives}

The objective of this study was to examine how contemporary wildfire activity and land use change affected discharge normalized sediment delivery from highly agricultural, semi-arid mountainous watersheds in the context of additional hydrologic and climatic controls. The fundamental approach was to examine changes in suspended sediment - discharge relationships over time in light of temporal trends in wildfire and agricultural activities. Increasing watershed burn area over time would be expected to result in increasing sediment production. Conversely, changes to less erosive agricultural technologies, such as increasing the proportional utilization of drip irrigation, would be expected to result in decreasing sediment production. Departure of sediment production trends from those expected on the basis of changes in a given control factor would be considered as evidence that the factor was not a dominant control on sediment production. Correlation of sediment production metrics with wildfire activities were then used to determine if wildfire disturbance also acted as a short term (annual to interannual) control on sediment production. Wildfire activity was expected to correlate positively with sediment production. Departure from this expected correlation between sediment production and wildfire would also indicate that wildfire was not a dominant control. 


\section{Study region}

\subsection{Physiography}

The Salinas River drains $11,605 \mathrm{~km}^{2}$ of the Central Coast Ranges of California from a maximum relief of $\sim 1,900 \mathrm{~m}$ with a mean discharge $\left(Q_{\text {mean }}\right)$ of $11.6 \mathrm{~m}^{3} / \mathrm{s}$ from the lowest gauge in the basin (S1, USGS gauge \# 11152500: Salinas R. near Spreckels) for the periods of 19312011 (Fig. 1). The regional climate is dry-summer subtropical — most annual precipitation falls as rain originating from winter storms, the largest of which often occur during strong El Niño years (Farnsworth and Milliman, 2003; Andrews et al., 2004). For this region 'water years' begin on 1 October of the previous calendar year and end on 30 September of the calendar year. A strong precipitation gradient extends from the wetter SW $(\sim 1000 \mathrm{~mm} / \mathrm{yr})$ to drier NE $(\sim 300$ $\mathrm{mm} / \mathrm{yr}$ ) region of the watershed due to predominant $\mathrm{S}-\mathrm{SW}$ impingement of storms (Andrews et al., 2004) and orographical forcing (Farnsworth and Milliman, 2003).

Geologic substrate is primarily Mesozoic sedimentary rock (Rosenberg and Joseph, 2009). The Salinas River valley consists of three lateral geomorphic zones - a riverbed, a bottomland, and flanking terraces, with one such terrace containing the major alluvial plain on the valley floor that is populated and used today. The bottomland is a broad bench situated lower than the surrounding plain and separated from it by well-defined side slopes. Though historically there was a well-defined, small, forested channel localized in the bottomland (Crespí and Brown, 2001), today the channel is primarily a broad, destabilized active zone that is intermittently well-defined in space and time as either a meandering thread or braided channel. The modern channel is lightly vegetated, with the abundance depending on the duration of 
interannual dry periods between floods, as these times allow pioneer grasses and willow shrubs to emerge though not necessarily persist.

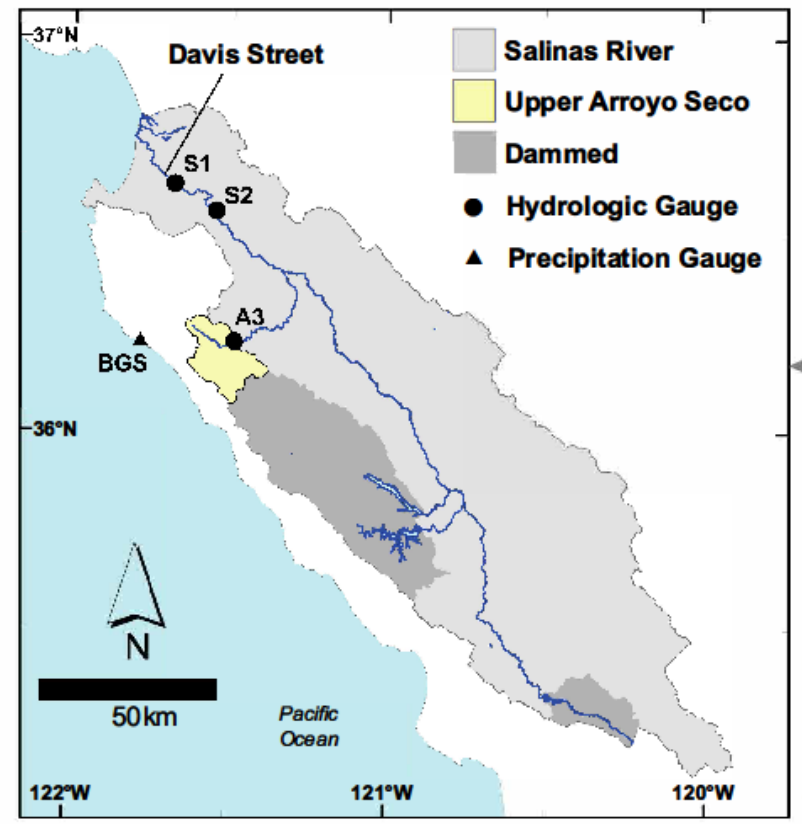

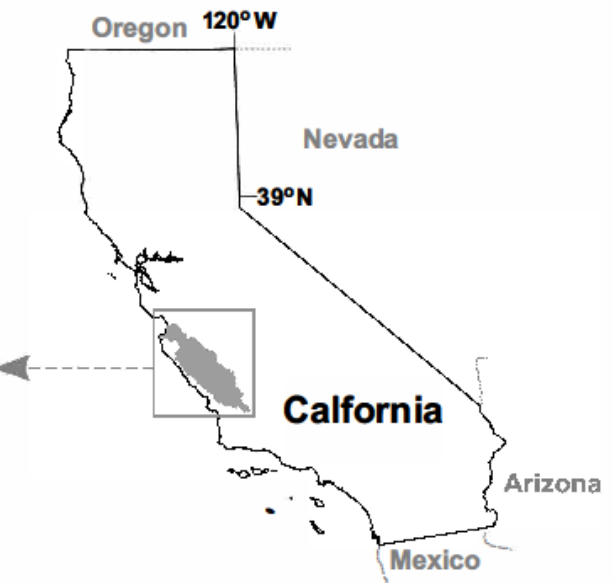

Figure 1. The Salinas River watershed. The locations of USGS hydrologic gauging stations are marked with circles and identification codes: S1 and S2 correspond to gauge names: Salinas $R$. near Spreckels and Salinas River near Chualar (USGS gauge numbers 11152500 and 11152300), respectively. The National Oceanographic and Atmospheric Administration precipitation gauge 'Big Sur State Park' is indicated with a black triangle and the label BGS.

\subsection{History of human impacts}

The Salinas valley has been influenced by humans and animals throughout its recorded history and likely thousands of years before the arrival of Europeans. Pre-historically, the Ohlone natives of the region used fire to maintain an open terrain on the main valley floor and to promote their food supply, whereas the hills and mountains around the valley were forested and home to large predators (Margolin, 1978). The moist bottomlands were well vegetated with cottonwoods, sycamores, live oaks, willows, and some pines and white oaks (Crespí and Brown, 2001). Archival records and drawings from the Spanish and Mexican era (1769-1849) indicate that the bottomlands were deforested in support of the development of the rancho economy prior to American conquest. Further, beaver were likely abundant in the river and important in its morphology and sediment dynamics, yet are now demonstrated to have been extirpated from the 
landscape as part of the maritime California fur trade during the Spanish and Mexican era (Lanman et al., 2013). Meanwhile, the higher plains adjacent to the bottomlands were grazed by some millions of free-ranging cattle during this era (Smith-Lintner, 2007), until the devastating drought of 1861-1865 ended California's cattle-based economy. Cattle also went into the bottomland to get water, especially during droughts when large holes were dug into the riverbed to provide livestock and people with access to the perennial groundwater for drinking (Fisher, 1945). Reclamation projects stimulated by new state laws promoting land use converted marshy areas around valley's sloughs into agricultural land during 1850-1870 (PAST Consultants LLC, 2010). According to records from American land surveyors and the British naturalist William Brewer who traveled the river corridor in the mid-1850s and early 1860s (e.g., Freeman, 1855; Brewer and Farquhar, 1966), the Salinas was a desolate, dry bed of wind-blown sand and treacherous quicksand at that time, yet newspapers also reported on devastating floods, such as in 1852 when the Salinas plain was inundated. Overall, a fundamental transformation in the landscape was wrought by Europeans, even as regional climate remained the same with no longterm trend throughout that period (based on analysis of the paleoclimate records used in Griffin and Anchukaitis, 2014), although the characteristic feature of the climate has been frequent recurrences of droughts and floods (Guinn, 1890; Lynch, 1931). Similar to the observed threshold change in sedimentary response to post-European land transformation in the Chesapeake Bay region (Kahn and Brush, 1994), the pre-European Salinas landscape was likely resilient to natural climatic events (e.g., droughts, wildfires, floods, and earthquakes), even with Ohlone fire practices, but after European land transformation the landscape became highly sensitive to perturbation. 
Today, the Salinas River is heavily changed due to modern land use and flow regulation. Excessive surface irrigation and the regional drought of 1880 were the major stimuli for the onset of groundwater pumping (Planert and Williams, 1995), fueled by the wood from the valley's remaining trees. By 1901 pumping was well underway, with wells drawing water from as deep as $75 \mathrm{~m}$ below the ground surface and lowering the water table below the ground by 3-5 m (Lapham and Heilman, 1901). Agriculture is now the largest anthropogenic disturbance in the watershed in terms of area, followed by urbanization and dam emplacement (Thompson and Reynolds, 2002). Three major dams were constructed on the mainstem and two major eastern tributaries from 1941-1965, impounding the runoff of some $1,970 \mathrm{~km}^{2}$, or about $17 \%$ of the total watershed, primarily in the mountainous subbasins in the wetter western mountains (Fig. 1). Urbanization has increased significantly in the basin over the past century but represented only $\sim 2 \%$ of land area by 2010 .

\subsection{Previous Studies}

The Salinas River watershed of central California was used as the test case for this study because of the preponderance of data documenting diverse hydrologic events in the watershed, and its history as a preeminent testbed for watershed-scale sediment flux over the last few decades. This work provided the initial forensic setting from which to explore the roles of wildfire and agricultural activity in a semi-arid, mountainous watershed. Previous studies found evidence for the primary role of the Salinas River in supplying sand to Monterey Bay (Porter et $a l ., 1979)$ and the significant reduction of coarse sediment export to the coast due to damming on the Salinas and neighboring Rivers (Willis and Griggs, 2003). External controls on decadal to inter-decadal scale fluvial sediment flux patterns have been further investigated in terms of El 
Niño Southern Oscillation (ENSO) cycles (Inman and Jenkins, 1999; Farnsworth and Milliman, 2003; Gray et al., 2015a). Integrated expressions of external and internal factors in the form of antecedent hydrologic conditions (i.e. discharge and drought history) that are affected by ENSO have also been examined as controls on suspended sediment discharge regimes (Gray et al., 2014; 2015a; 2015b). One previous study has also addressed the importance of wildfire in controlling the sediment export from a major Salinas tributary (Warrick et al., 2012).

Inman and Jenkins (1999) conducted a regional scale study on suspended sediment flux from central and southern California coastal rivers with a focus on episodic events and their relationship to regional climate cycles. They found that large events dominated sediment transfer from the rivers in this region, including the Salinas, and that decadal scale wet and dry cycles lead to concomitant increases and decreases in suspended sediment flux to the ocean. Their approach to calculating suspended sediment discharge through the lower Salinas utilized a rating curve constructed from data collected by the USGS gauge station near Spreckels, CA (S1, see Fig. 1) during water years 1969-1979, which they applied to monthly averages of daily water discharge from 1944-1995, resulting in an estimated average annual suspended sediment discharge of 1.7 $\mathrm{Mt} \mathrm{yr}^{-1}$. Farnsworth and Milliman (2003) also examined the role of large discharge events in the estimation of total suspended sediment load at gauge S1, and used the same set of S1 USGS data to compute a power law rating curve that was then applied to daily water discharge data from 1930-2000 for an average annual suspended sediment discharge of 3.3

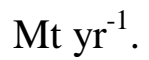

Gray et al. $(2014 ; 2015 a ; 2015 b)$ thoroughly investigated suspended sediment dynamics in the Salinas River in relation to climatic and hydrological drivers. It was found that $C_{S S^{-}} Q$ behavior was influenced by antecedent hydrologic conditions at event, annual, interannual and 
decadal time scales (Gray et al., 2014; 2015a), and that the temporal trend in discharge-corrected suspended sediment concentrations was negative over the 1967-2011 period of record (Gray et al., 2015a). Notably, no change in the relationship between precipitation and discharge was found over this time period (Gray et al., 2015a). By taking these factors and the temporal dependence of sediment behavior into consideration, the average annual suspended sediment flux was estimated as 2.1 to $2.4 \mathrm{Mt}$ (Gray et al., 2015b).

The Arroyo Seco drains $\sim 700 \mathrm{~km}^{2}$ of the wetter western mountains in the Salinas River watershed. The majority of the Arroyo Seco remains largely undeveloped and is undammed, unlike the other major Salinas River subbasins in this region. For this reason, the Arroyo Seco is a significant contributor of water and sediment to the Salinas River (Warrick et al., 2012). Warrick et al. (2012) found that sediment export from the Arroyo Seco was highly controlled by the sequence of wildfire and subsequent high precipitation/discharge events. Nearly complete burning of the upper Arroyo Seco watershed in the summers of 1977 and 2008 facilitated a pairwise comparison of post fire sediment flux past gauge A3 (USGS gauge \# 11151870: Arroyo Seco near Greenfield), in relation to storm timing and intensity differences (Fig. 1). A rare ( 10-year return interval), high intensity wet season during the 1978 water year led to an annual sediment flux 100x pre-fire, while moderate precipitation in 2009 and 2010 resulted in only 5x and 9x increases, respectively. Warrick et al. (2012) estimated that the Arroyo Seco's post-fire sediment flux may have caused the total Salinas River sediment to export to double in 1978. 


\section{Methods}

3.1. Data

Data used in this study consisted of three types: instantaneous suspended sediment concentration and discharge observed in the Salinas River, geographical and temporal wildfire data, and land cover and land use geospatial data. A brief account of fluvial sample collection and preparation is presented here - for more details see Gray et al. (2014).

\subsubsection{The $C_{S S} Q$ relationship}

Discharge and a number of fluvial constituents, including suspended sediments, are monitored in the lower Salinas River at S1 and S2 (USGS gauge \# 11152300, Salinas River near Chualar) (Fig. 1). This study was based on 286 suspended sediment samples collected by the USGS between 1967 and 2010 (USGS NWIS, 2015), and 44 by the authors between 2008 and 2011 from gauging stations S1 and S2 and the Davis Street bridge crossing $4 \mathrm{~km}$ downstream from S1 (Fig. 1). Potential biasing of the suspended sediment data set in terms of hydrologic regime representation and temporal distribution was examined and discounted in Gray et al. (2014). Paired samples were collected by the authors from the water surface at cross-channel stations of one-quarter, one-half, and three-quarters wetted channel width (Gray et al.,2014), which were then processed for $C_{S S}$ and particle size distribution as per Gray et al. (2010).

Suspended sediment samples for this study were collected from the surface of river flow. For this reason coarse suspended sediment particles were expected to be underrepresented. Sediment suspension calculations by particle size based on the characteristics of the highest and 
lowest flows showed that fine particles in the clay to silt range (diameter $(D)<62.5 \mu \mathrm{m}$ ) should be uniformly distributed throughout the vertical profile (Rouse, 1937, Hill et al., 1988). Based on these estimations, analysis of the suspended sediment samples collected by the authors was restricted to fine particles of $D<62.5 \mu \mathrm{m}$. Values for fine suspended sediment concentration $\left(C_{S S f}\right)$ were calculated by multiplying $C_{S S}$ by the proportion of sediment occurring in the fine fraction:

$$
C_{S S f}=\frac{\mathrm{C}_{S S} \times(\% \text { particles }<62.5 \mu \mathrm{m})}{100}
$$

The USGS collected flow-integrated $C_{S S}$ samples from the Salinas River at locations corresponding to S1 and S2 from water years 1969 to 1986 and 1967 to 2010, respectively (USGS NWIS, 2015). The 277 USGS samples used in this study represented a given discharge event and were associated with both instantaneous discharge and particle size data. The USGS samples were processed by sieving to establish the relative contribution of fine, and sand (2000 $\mu \mathrm{m}>\mathrm{D}>63.5 \mu \mathrm{m})$ fractions. The $C_{S S f}$ for these samples was calculated using Eq. (1), and the concentration of sand suspended sediment $\left(C_{S S s}\right)$ was obtained by subtracting $C_{S S f}$ from $C_{S S \text {. }}$ Hereafter, the term $C_{S S}$ is used generally when referring to tests that were conducted separately on $C_{S S f}$ and on $C_{S S s}$.

All suspended sediment data from the USGS were associated with measured instantaneous discharge values. Samples collected by the authors were assigned discharge values through linear interpolation between adjacent 15-min discharge data from the appropriate USGS gauge. Davis Street sample discharge was estimated from the S1 record of 15-min discharge data by applying a time lag to account for the transit of flow stage downstream, and 
linearly interpolated when the lagged time fell between 15-min discharge records.

Rating curves were used in this study to represent bivariate relationships between $C_{S S f}$ and $Q(\mathrm{n}=330)$, and $C_{S S s}$ and $Q(\mathrm{n}=248)($ Fig. $2 \mathrm{a}, \mathrm{b})$. The residual of observed vs. rating curve estimates of $C_{S S}$ for were then used to describe changes in $C_{S S^{-}} Q$ relationships over time (Fig. 2c, d). The rating curves were constructed with $2^{\text {nd }}$ order polynomial localized regression (LOESS) techniques applied to log-transformed data (Cleveland, 1979; Helsel and Hirsch, 2002; Gray et al., 2014), and were not corrected for log-transform bias as back-transformation for flux estimation in original units was not conducted here (Fig. 2a, b). Residuals were obtained by subtracting the rating curve estimate of $C_{S S}$ from the observed value of $C_{S S}$ for each sample, in effect correcting sample $C_{S S}$ for the influence of $Q$ (Fig. 2c, d). These residual values then formed the basis for subsequent temporal trend and correlation analyses with potential forcing factors.

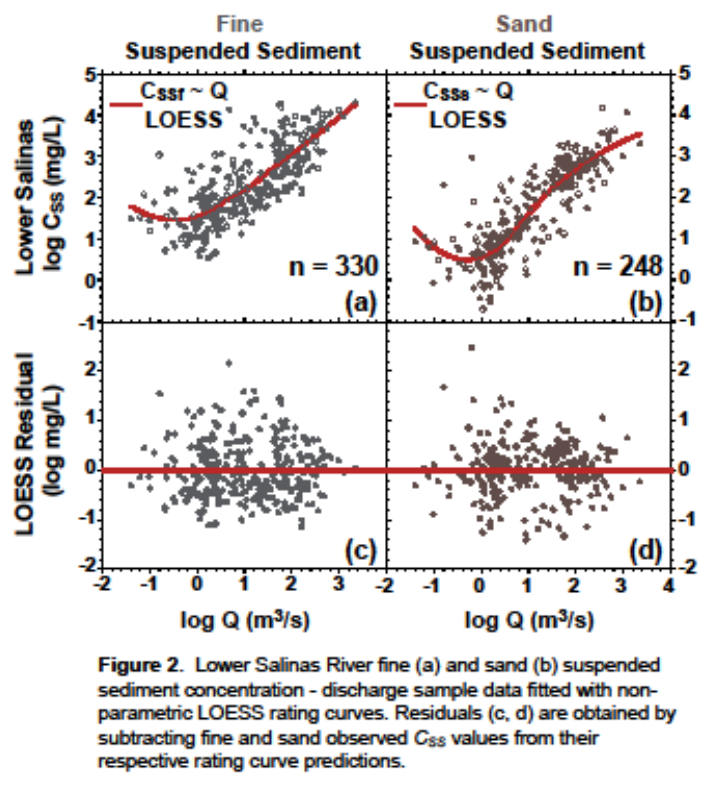




\subsubsection{Effective burn area}

Geographical and temporal wildfire data recorded by the California Department of Forestry and Fire Protection (Cal Fire) Fire Resource Assessment Program (FRAP) from 19112010 were clipped to the geographic extent of the Salinas watershed (Cal Fire, 2015).

Contributing areas behind dams were masked for the time periods of their operation, as the trapping efficiency of these dams was previously estimated as $>90 \%$ for fine sediment (Gray $e t$ $a l ., 2015 \mathrm{~b})$. The areal extent of fires in undammed portions of the watershed was then summed by year for further computations of effective burn area (Fig. 3).

The lasting, time-dependent effect of a given wildfire, or set of wildfires, on the landscape can be modeled as "effective" burn area, which is the initial burn area(s) modified by standard exponential decay functions operating over the elapsed time since the fire (Lavé and Burbank, 2004; Warrick and Rubin, 2007). The total effective burn area for a basin (EBA) at any given time is the sum of all effective burn areas. The range of relevant half-life $\left(t_{1 / 2}\right)$ values for the $E B A$ decay function found for semiarid southern California systems is between $0.5-14$ years, with 1.4 years identified as the best fit for the Arroyo Seco (Lavé and Burbank, 2004; Warrick and Rubin, 2007; Warrick et al., 2012). In this study the EBA approach was applied to annual burn area data with a range of $t_{1 / 2}$ values from $0.5-10$ years in 0.5 year steps. As most Salinas fires occur during hot, dry summers, the $E B A$ associated with a given $C_{S S}$ sample was calculated by summing of effective burn area contributions from all previous years, with the year before the water year (starting on October 1) of the sample treated as $t=0$, while the annual burn area from the water year of the sample was excluded. 


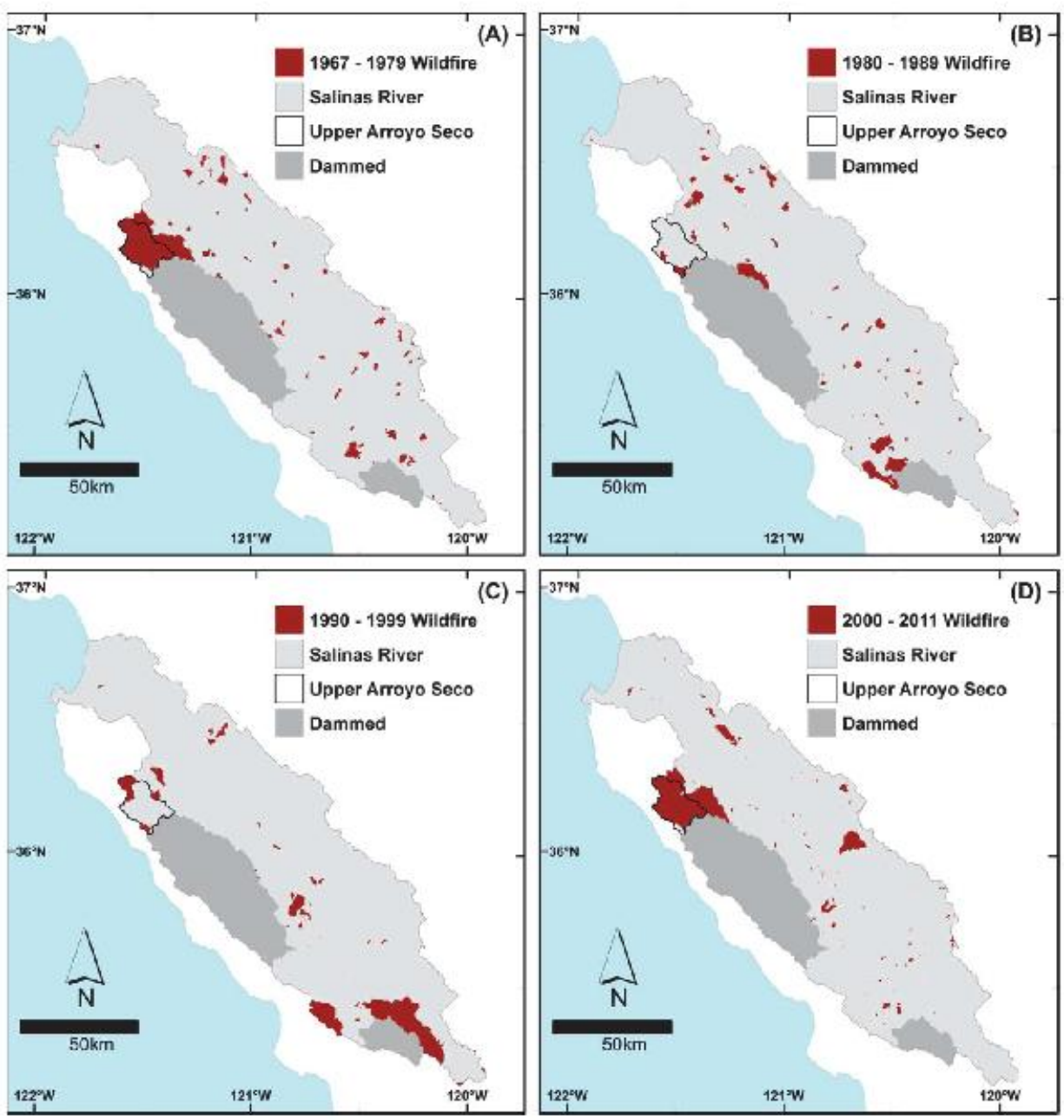

Figure 3. Wildfires in the Salinas River watershed marked in red and organized roughly by decade, with shaded regions illustrating the masking of dammed contributing areas.

\subsubsection{Agricultural data}

Spatial coverage of crops by year from 1965-2011 was obtained from the Monterey County Agricultural Commissioner's Office Crop Reports and sorted into 'field' and 'row' crops (Monterey County, 2015a). Data on the areal coverage agriculture by irrigation technique from 1993-2010 and urbanization from 1984-2010 were extracted from Monterey County, 2015b). 


\subsection{Data analysis}

Testing for the control of wildfire and agricultural activity on sediment production in the lower Salinas River was based on comparing the temporal trends of ( $C_{S S} \sim Q$ ) LOESS residuals for both fines and sand with the temporal trends of metrics for effective wildfire burn area, bulk and crop specific agricultural areas, and areas under given irrigation types. Temporal trend analysis was conducted with Mann-Kendall and linear regression. It was hypothesized that the decreasing $C_{S S^{-}} Q$ relationships found in the lower Salinas were caused by one or a combination of the following changes in sediment controls over the sample period: (i) decreased wildfire activity, (ii) decreased agricultural land area, (iii) changes in agricultural composition to less erosive crops, or (iv) changes to less erosive irrigation techniques. All data sets were examined for temporal trends in light of the 1967-2011 base period of $C_{S S}$ data, although the irrigation technique data set did not begin until 1993. Factors with statistically insignificant temporal trends $(\mathrm{P} \leq 0.05)$ and/or trend directions opposing those expected in light of decreasing $C_{S S^{-}} Q$ were eliminated as potential controls.

A correlation test was also performed between $\left(C_{S S} \sim Q\right)$ LOESS residuals and the wildfire burn area metric $E B A$, as short term (annual to interannual) responses in basin scale sediment production would be expected from wildfire disturbances. A significant ( $\mathrm{P}$ value $\leq$ 0.05) positive correlation between the wildfire and suspended sediment magnitudes would be considered indicative of wildfire as a potential dominant control on decadal scale trends in sediment production, since wildfire has been generally found to increase the production of sediment to a greater degree than water in the steep, brush dominated environments typical of the primary source areas in the Salinas River (Warrick and Rubin, 2007; Warrick et al., 2012;

Hubbert et al., 2012). Correlation tests were not performed on the agricultural metrics as they 
were expected to only produce decadal to inter-decadal sediment production responses rather than abrupt shifts in sediment supply dynamics due to the slow rate of change of these factors.

As Warrick et al. (2012) had found that wildfire affected 100 times more sediment yield from the Arroyo Seco subbasin when followed by a winter of intense storm events, $E B A$ was also examined in concert with peak daily $Q$ for each year. The values of $\left(C_{S S} \sim Q\right)$ LOESS residuals for years with high $E B A$ values were then compared with consideration given to the peak daily $Q$ experienced by these years, to determine if the convolution of wildfire and subsequent large storms was responsible for temporal patterns of suspended sediment behavior at the annual scale.

\section{Results}

The largest total annual burn areas during the period of sediment record in the undammed Salinas Watershed occurred during the 1977, 1985 and 2008 dry seasons, with burn areas of 701, 753 and $975 \mathrm{~km}^{2}$, respectively (Fig. 4a). This sequence of large annual burn areas spaced every 10-20 years, with increasing magnitudes over time, resulted in an EBA time series that exhibited positive temporal trends, the strength of which increased with increases in the $t_{1 / 2}$ parameter (Table 1, Figure 4b). Increasing $t_{1 / 2}$ led to increases in $E B A$ with time as the periodicity between years of high burn area became short relative to the simulated rate of burn area decay (Fig. 4b). 


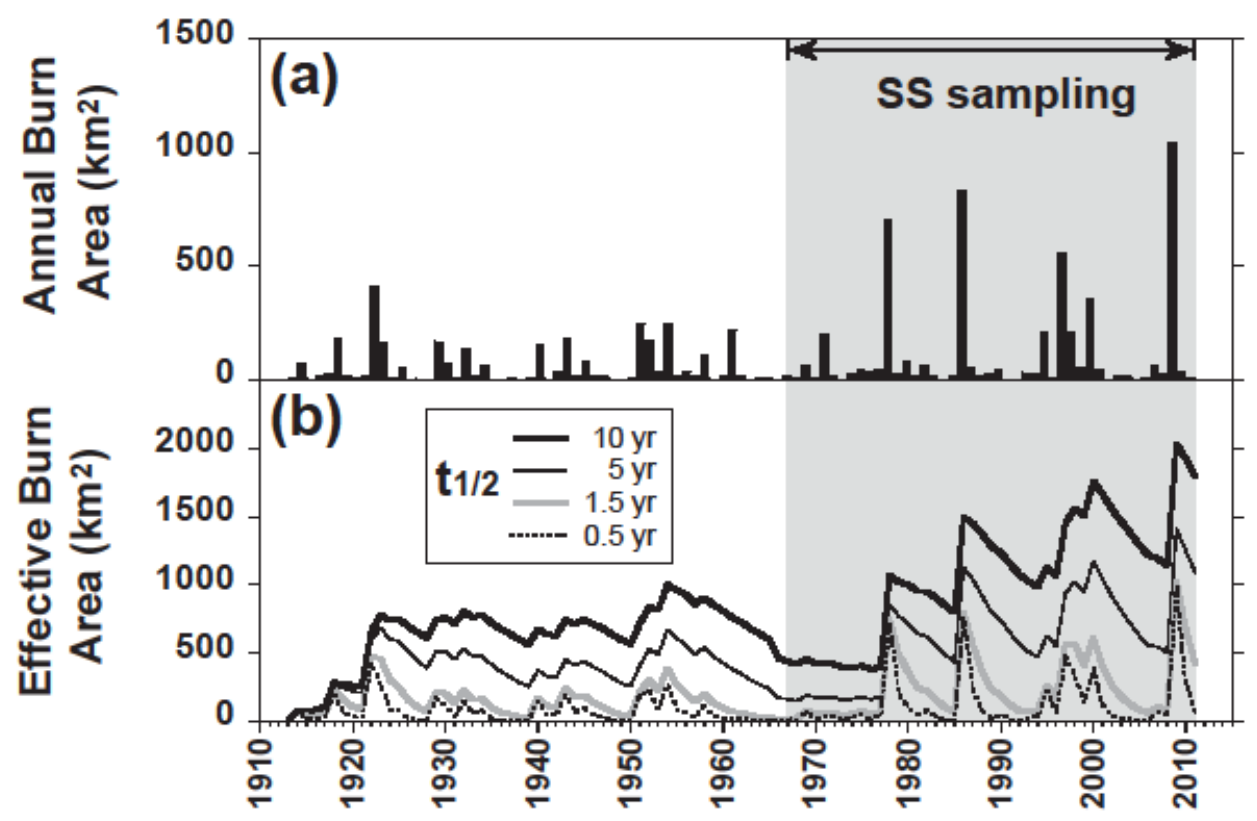

Figure 4. Fire history of the Salinas watershed. (a) Annual burn area; and (b) effective burn area values calculated using exponential decay functions with specified half-life (t1/2) constants. Shaded area indicates temporal extent of USGS and UCD suspended sediment sampling in the lower Salinas.

Table 1. Temporal trend and correlation analysis results.

\begin{tabular}{|c|c|c|c|c|c|c|c|}
\hline \multirow[b]{2}{*}{ Analysis } & \multirow[b]{2}{*}{ Dependent Variable } & \multirow[b]{2}{*}{ Independant variable } & \multicolumn{2}{|c|}{ Mann-Kendall } & \multicolumn{3}{|c|}{ Linear Regression } \\
\hline & & & Tau & $\begin{array}{c}\mathrm{P}- \\
\text { value }\end{array}$ & Coefficient & $\mathrm{R}^{2}$ & $\begin{array}{c}\mathrm{P}- \\
\text { value }\end{array}$ \\
\hline \multirow{6}{*}{ Temporal trends } & $\left(C_{S S f} \sim Q\right)$ LOESS residuals & Time & -0.20 & $* * *$ & $-3.0 \mathrm{E}-05$ & 0.06 & $* * *$ \\
\hline & $\left(C_{s s s} \sim Q\right)$ LOESS residuals & Time & -0.14 & $* * *$ & $-3.0 \mathrm{E}-05$ & 0.05 & $* * *$ \\
\hline & $E B A, t_{1 / 2}=0.5$ years & Time & 0.16 & ns & 3.4 & 0.02 & ns \\
\hline & $E B A, t_{1 / 2}=1.5$ years & Time & 0.34 & $* *$ & 6.9 & 0.11 & $*$ \\
\hline & $E B A, t_{1 / 2}=5$ years & Time & 0.44 & $* * *$ & 18.5 & 0.48 & $* * *$ \\
\hline & $E B A, t_{1 / 2}=10$ years & Time & 0.58 & $* * *$ & 30.6 & 0.73 & $* * *$ \\
\hline \multirow{4}{*}{$\begin{array}{c}\text { Fine sediment } \\
\text { correlation with EBA }\end{array}$} & $\left(C_{S S f} \sim Q\right)$ LOESS residuals & $E B A, t_{1 / 2}=0.5$ years & -0.14 & $* * *$ & $-2.5 \mathrm{E}-04$ & 0.01 & ns \\
\hline & $\left(C_{S S f} \sim Q\right)$ LOESS residuals & $E B A, t_{1 / 2}=1.5$ years & -0.15 & $* * *$ & $-4.4 \mathrm{E}-04$ & 0.05 & $* * *$ \\
\hline & $\left(C_{S S f} \sim Q\right)$ LOESS residuals & $E B A, t_{1 / 2}=5$ years & -0.20 & $* * *$ & $-4.2 \mathrm{E}-04$ & 0.08 & $* * *$ \\
\hline & $\left(C_{\text {SSf }} \sim \mathrm{Q}\right)$ LOESS residuals & $E B A, t_{1 / 2}=10$ years & -0.19 & $* * *$ & $-3.1 E-04$ & 0.08 & $* * *$ \\
\hline \multirow{4}{*}{$\begin{array}{c}\text { Sand } \\
\text { correlation with EBA }\end{array}$} & $\left(\mathrm{C}_{\mathrm{SSs}} \sim \mathrm{Q}\right)$ LOESS residuals & $E B A, t_{1 / 2}=0.5$ years & 0.08 & $*$ & 4.1E-05 & $\begin{array}{c}3.4 \mathrm{E}- \\
04\end{array}$ & ns \\
\hline & $\left(C_{s S s} \sim Q\right)$ LOESS residuals & $E B A, t_{1 / 2}=1.5$ years & $\begin{array}{l}5.6 \mathrm{E}- \\
03\end{array}$ & ns & $-4.6 \mathrm{E}-05$ & $\begin{array}{l}5.1 \mathrm{E}- \\
04\end{array}$ & ns \\
\hline & $\left(C_{S s s} \sim Q\right)$ LOESS residuals & $E B A, t_{1 / 2}=5$ years & -0.04 & ns & $-2.1 \mathrm{E}-05$ & 0.02 & * \\
\hline & $\left(C_{\text {SSs }} \sim Q\right)$ LOESS residuals & $E B A, t_{1 / 2}=10$ years & -0.11 & $*$ & $-2.4 \mathrm{E}-04$ & 0.04 & $* *$ \\
\hline
\end{tabular}

All temporal trends computed for the base period of water years 1967-2011. $C_{S S f}=$ fine suspended sediment concentration; $C_{S S s}=$ sand suspended sediment concentration; LOESS = localized regression; EBA = Effective Burn Area. ns = P-value $\geq 0.05 ; *=\mathrm{P}-$ value $<0.5 ; * *=\mathrm{P}$ value $<0.01,{ }^{* * *}=$ P-value $<0.001$ 
Over the same 1967-2011 time period discharge-corrected $C_{S S f}$ and $\mathrm{C}_{\text {SSs }}$ displayed significantly decreasing temporal trends (Table 1). Thus, EBA, and discharge corrected $C_{S S f}$ and $C_{S S s}$ time series exhibited opposing temporal trends. Correlation analysis of suspended sediment behavior in relation to $E B A$ confirmed that these opposing temporal trends resulted in generally negative relationships between $C_{S S}$ and $E B A$ (Table 1). All methods of correlation analysis found that $\left(C_{S S f} \sim Q\right)$ LOESS residuals decreased with increasing $E B A$, and that increasing the $t_{1 / 2}$ of the $E B A$ calculation served to increase the strength of the negative correlation. Sand results were mixed, with low $t_{1 / 2} E B A$ values yielding slightly positive, insignificant trends, and higher $t_{1 / 2} E B A$ values producing significant, slightly negative trends.

Water years with high $E B A$ values experienced a wide range of hydrologic intensities including conditions that produced very low and very high discharge (Fig. 5). Of the eight years with $E B A\left(t_{1 / 2}=1.5 \mathrm{yr}\right)>500 \mathrm{~km}^{2}$ between 1967 and 2011 (labeled by year in Fig. 5), maximum daily $Q$ ranged between 27.8 and $1161 \mathrm{~m}^{3} / \mathrm{s}$. $\log \left(C_{S S} \sim Q\right)$ LOESS residuals plotted for suspended fines and sand for these high $E B A$ years showed no consistent pattern of increased $C_{S S}$ due to $E B A$ alone (Fig. 6). Two years with high $E B A$ values (1978 and 1998) experienced maximum daily $Q>1000 \mathrm{~m}^{3} / \mathrm{s}$, or $>90 \cdot Q_{\text {mean }}$. Samples from 1978 exhibited mean log residual values of 0.144 and 0.195 for fines and sand, respectively, which translates to $C_{S S}$ values $39 \%$ and $56 \%$ greater than the rating curve estimates fitted to the complete data set. Only a single sample was available for 1998, which had a positive sand residual and slightly negative fine residual. Indeed, of the 66 fine sediment samples from high $E B A$ years, all but 18 plotted in negative residual space, and 11 of the 18 positive residual values were from 1978. As a group, the high $E B A$ sand samples had an average residual value of $\sim 0$, though most of the positive 
residuals were from samples collected in 1978 as well. Thus, although 1978 seems to have produced higher $C_{S S}$ in coincidence with high magnitude rainfall/runoff events acting upon a watershed with a relatively high proportion of burn area, there is a lack of evidence for this phenomena exerting significant control on suspended sediment behavior during other high $E B A /$ high $Q$ years, which was unexpected.

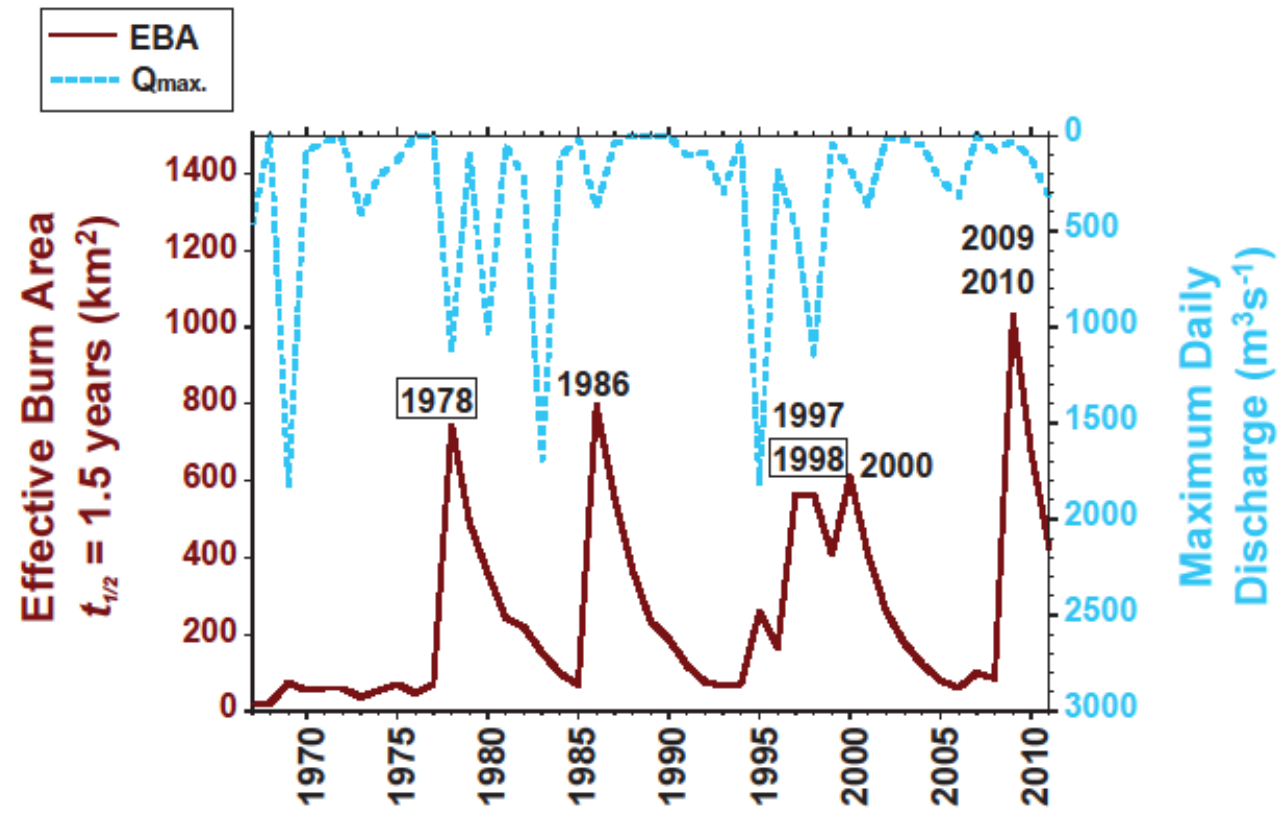

Figure 5. Plots of the Salinas River watershed effective burn area calculated with a half-life value of 1.5 years, along with the maximum daily water discharge at the S1 gauge by water year. Labeled years have effective discharge values > $500 \mathrm{~km}^{2}$. Boxed years (1978 and 1998) are those with high effective burn area and high maximum daily discharge values. 


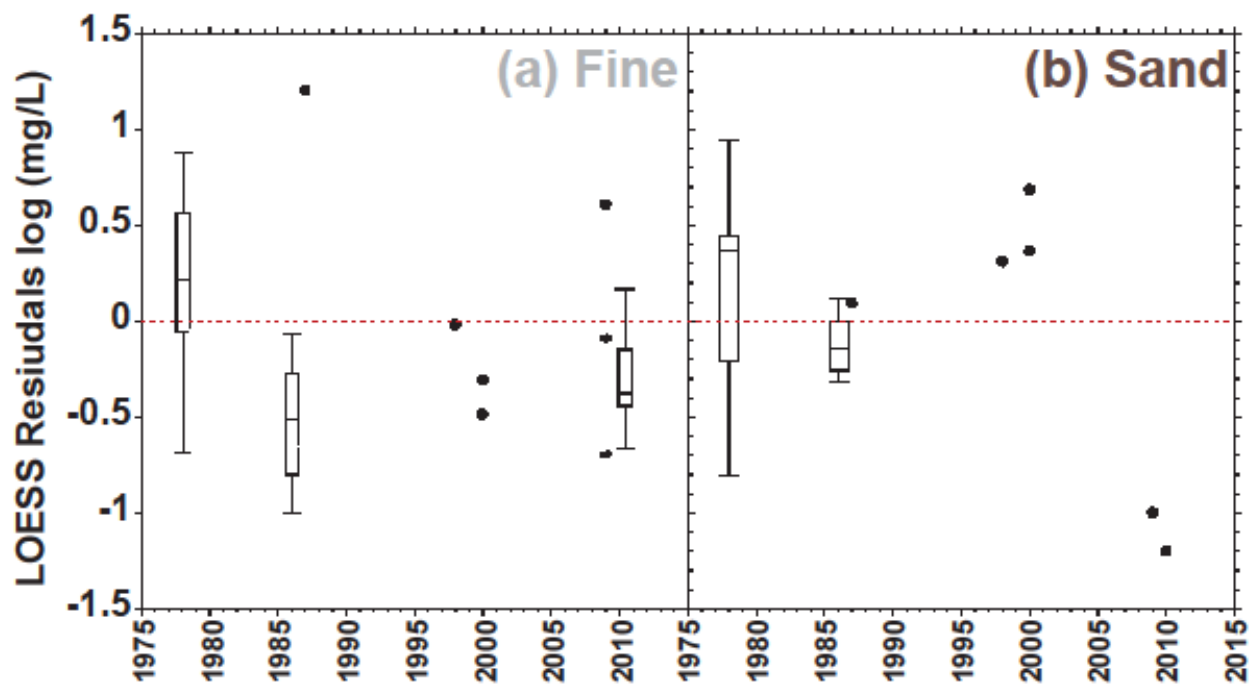

Figure 6. Box and whisker plots of (a) fine and (b) sand $\left(C_{S S} \sim Q\right)$ LOESS residuals for years with the highest effective burn area values. Whiskers mark the maximum and minimum values, upper and lower boxes denote quartiles, and central hash is the median. Years with less than five samples have samples plotted individually.

Beginning in the mid-1960s dry (mostly non-irrigated) field products like barley and animal feed declined and root products such as sugar beets and potatoes all but disappeared (Table 2, Fig. 7a). Intensively irrigated row crops and utilization of land for multiple cropping seasons expanded, including rapid increases in leaf lettuce beginning in the early 1980s, while grape production expanded rapidly from 6-141 $\mathrm{km}^{2}$ between 1971 and 1974, mostly on converted field crop and grazing lands. As a result of these crop changes and the limited use of efficient drip irrigation ( $<15 \%$ of irrigation area at the time), groundwater withdrawals are estimated to have increased during the first half of the suspended sediment record (Brown and Caldwell, 2015). Monterey County, which is mostly contiguous with the Salinas watershed, began recording groundwater withdrawals in 1993 (Figure 7b). Between 1993 and 2010 total ground water extraction actually decreased from 0.62 to $0.57 \mathrm{~km}^{3}$, although irrigated agricultural land area increased from 702 to $732 \mathrm{~km}^{2}$ and total crop area increased from 1270 to $1588 \mathrm{~km}^{2}$ (Figure 7a,b). Decreased extraction despite crop intensification was largely enabled by 
increases in irrigation efficiency, including decreased water losses during transport to fields and basin-wide implementation of drip irrigation (Fig. 7c). Drip irrigation is known to produce much less off-field sediment transport during the irrigation season than sprinkler and furrow irrigation techniques. Thus, large scale conversion from furrow to drip irrigation led to decreases in irrigation water use, and may have also played a role in decreasing Salinas River suspended sediment concentrations in the latter $20^{\text {th }}$ to early $21^{\text {st }}$ centuries.

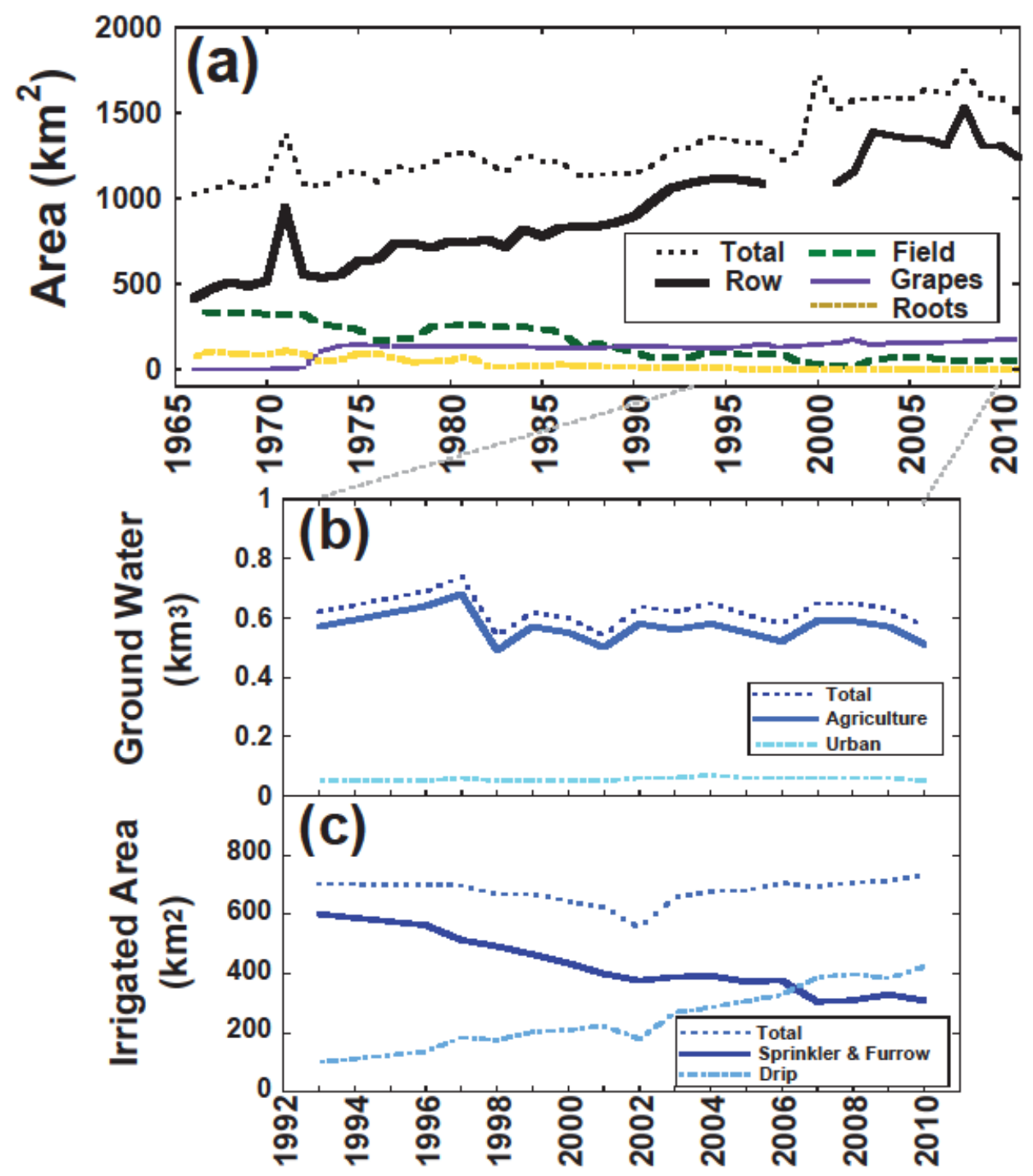

Figure 7. Monterey County land and water use by year. (a) Agricultural crop areas: row crops include vegetables, lettuce, strawberries, etc., field crops are mostly grains and animal feed, roots include sugar beets and potatoes. (b) Ground water by user group. (c) Agricultural irrigation practices. 
Table 2. Temporal trends of crop areas and ground water consumption in Monterey County

\begin{tabular}{|c|c|c|c|c|c|c|c|}
\hline \multirow[b]{2}{*}{ Group } & \multirow[b]{2}{*}{ Dependent Variable } & \multirow[b]{2}{*}{ Base Period } & \multicolumn{2}{|c|}{ Mann-Kendall } & \multicolumn{3}{|c|}{ Linear Regression } \\
\hline & & & Tau & P-value & Coefficient & $\mathrm{R}^{2}$ & P-value \\
\hline \multirow{3}{*}{$\begin{array}{c}\text { Ground Water } \\
\text { Extraction }\end{array}$} & Total & $1993-2010$ & 0.06 & ns & $-1.9 \mathrm{E}-03$ & 0.04 & ns \\
\hline & Agricultural & $1993-2010$ & $\begin{array}{c}- \\
0.09\end{array}$ & ns & $-2.7 \mathrm{E}-03$ & 0.08 & ns \\
\hline & Urban & 1993-2010 & 0.38 & ns & $5.7 \mathrm{E}-04$ & 0.21 & ns \\
\hline \multirow{3}{*}{ Irrigated Area } & Total & $1993-2010$ & 0.28 & ns & 2.1 & 0.06 & ns \\
\hline & Sprinkler and Furrow & $1993-2010$ & 0.85 & $* * *$ & -17.4 & 0.92 & $* * *$ \\
\hline & Drip & 1993-2010 & 0.88 & $* * *$ & 19.5 & 0.94 & $* * *$ \\
\hline \multirow{5}{*}{$\begin{array}{l}\text { Agricultural } \\
\text { Crops }\end{array}$} & Total & $1966-2010$ & 0.69 & $* * *$ & 12.9 & 0.72 & $* * *$ \\
\hline & Row & $1966-2010$ & 0.84 & $* * *$ & 21.2 & 0.91 & $* * *$ \\
\hline & Field & $1966-2011$ & $\begin{array}{c}- \\
0.77\end{array}$ & $* * *$ & -7.3 & 0.85 & $* * *$ \\
\hline & Grapes & $1966-2012$ & $\begin{array}{c}0.54 \\
-\end{array}$ & $* * *$ & 2.9 & 0.55 & $* * *$ \\
\hline & Roots & $1966-2010$ & 0.83 & $* * *$ & -2.4 & 0.79 & $* * *$ \\
\hline
\end{tabular}

ns $=\mathrm{P}$-value $\geq 0.05 ;^{*}=\mathrm{P}$-value $<0.5 ;^{* *}=\mathrm{P}$-value $<0.01, * * *=\mathrm{P}$-value $<0.001$

\section{Discussion}

Decreasing trends in suspended sediment concentration-discharge relationships were observed in the lower Salinas River from 1967-2011 despite increasing activities of wildfire and agriculture in the watershed over this period. Increases in effective burn area (Warrick and Rubin, 2007) and total crop area (Brush, 1989; Pasternack et al., 2001) have been generally found to increase sediment production at the watershed scale. Shifts in crop structure were dominated by a rise in row crops over this time period, which would also have been expected to increase sediment production. Row crop fields of are often left bare over the winter, rendering them prone to rainfall/runoff driven erosion, and degradation of the necessary drainage networks of earthen ditches can result in further increases in sediment export (Tanji et al., 1980; Tanji et al., 1983).

With the exception of changes in irrigation practices, potential control of decreasing suspended sediment loads from other anthropogenic activities can be discounted due to limited 
areal extent or timing. Urbanization increased, but only to approximately $2 \%$ of the Salinas River watershed area. While urbanization can lead to decreases in discharge-corrected $C_{S S}$ values by increasing the production of runoff from precipitation without concomitant increases in sediment production (Warrick and Rubin, 2007), no shift in the $P-Q$ relationship was observed in the Salinas River between 1967 and 2011 (Gray et al., 2014). Conversely, the damming of Salinas River subbasins and attendant sediment trapping has been estimated to have significantly decreased sediment flux relative to pre-dammed conditions (Willis and Griggs, 2003). However, dam emplacement in the Salinas Watershed occurred before the period of suspended sediment record, and the trapping characteristics of their reservoirs are not expected to have changed significantly over the intervening years (Gray, 2014).

Wildfire activity was insufficient to counteract the negative inter-decadal trend in suspended sediment load, even though the years with the highest effective burn areas in the Salinas River watershed fell toward the end of the record. There was some indication that the large fires preceding the 1978 water year, coupled with the high $Q$-producing storm events of that year, may have increased suspended sediment load in agreement with the findings of Warrick et al. (2012). However, other years with high effective burn areas and relatively high $Q$-intensities did not express consistent increases in $C_{S S}$.

The lack of wildfire control on inter-decadal scale trends in sediment loads may be due to issues of scale and the areal extent of burning. Often findings of dominant wildfire control come from studies of small, headwater catchments that have experienced burning over a high proportion of land area (e.g. Florsheim et al., 1991; Cannon, 2001; Lavé and Burbank, 2004; Warrick et al., 2012). Indeed, the suspended sediment flux from the Arroyo Seco subbasin was found by Warrick et al. (2012) to be highly controlled by the coincidence of wildfire and large 
storms on the basis of two instances of nearly complete burning of the watershed's oak and chaparral shrublands. The role of fire in maintaining chaparral vegetation communities and dominating sediment production in the semi-arid foothills and low mountains typical of coastal central and southern California has been extensively reported (Hanes, 1971; Rice, 1982;

Minnich, 1983; Florsheim et al., 1991; Mensing; 1999; Keeley and Fotheringham, 2003; Mortiz, 2003; Wohlgemuth and Hubbert, 2008; Keeley and Zeedler, 2009, Hubbert et al., 2012; Staley et al., 2014). In contrast, the undammed Salinas River watershed is an order of magnitude larger than the Arroyo Seco, with about half the average relief, and extensive agricultural development consisting of irrigation agriculture in lowlands and extensive grasslands on lower foothill slopes. As a result, even the largest $E B A$ calculated for the Salinas River were only $10 \%$ of the undammed watershed $\left(985 \mathrm{~km}^{2}, t_{1 / 2}=1.5\right.$ years, water year 2009$)$.

Thus the larger land area of the Salinas River watershed with numerous tributary drainages and divides and attendant mosaics of vegetation and microclimates has resulted in a mosaic of small wildfires relative to watershed size during any given fire season. Disconnected fire patches would be expected to produce less effective transfer of fire generated hillslope sediments to channels, in contrast to that of a completely burned watershed. Lowlands in the mainstem drainage network of the Salinas River also likely present a sink that moderates the signal of hillslope sediments produced from burned land surface, further obscuring the signature of more extensive burn years (Gray et al., 2014). Lavé and Burbank (2004) found a similar disappearance of wildfire control on inter-decadal scale sediment production when scaling up from small, $10^{-1}$ to $10^{1} \mathrm{~km}^{2}$ scale headwater subbasins to $10^{2} \mathrm{~km}^{2}$ scale watersheds in the San Gabriel Mountains of the southern California. Furthermore, semi-arid systems with intermittent flow and high discharge losses to groundwater recharge like the lower Salinas River tend to have 
longer residence times for suspended sediment due to increased incidence of in-channel deposition, particularly during flows into dry channels (Tanji et al., 1983; López-Tarazón et al., 2011).

Previous and continuing alterations to the Salinas River and its watershed may have exacerbated the attenuation of hillslope sediment production signals by destabilizing the channelized system of the lower Salinas and drawing down the ground water table. Widespread deforestation along the banks of the lower Salinas River in the $19^{\text {th }}$ century seemed to have decreased bank strength and led to a transition from a single meandering channel (Crespí and Brown, 2001) to a disorganized sandy active corridor, with localized and incipient braiding, which persists today. Intensive groundwater pumping remains above replacement (Brown and Caldwell, 2015), which could further exacerbates this scenario of lowland moderation of highland sediment production signatures by increasing the proportion of channelized flow abstracted to groundwater recharge (Planert and Williams, 1995). Indeed, early wet season flows have been observed to completely attenuate before reaching gauges $\mathrm{S} 1$ and $\mathrm{S} 2$, and thus completely depositing their suspended sediment loads into the channel (Gray et al., 2014).

A more direct human cause of the overall negative trend in $C_{S S}$, and the period of low $C_{S S f}$ that has persisted since the mid-1990s, is the conversion of agricultural operations to drip irrigation. Previously dominant methods of irrigation, particularly furrow, were known to produce large amounts sediment from off field transport and irrigation canal erosion (e.g. Tanji et al., 1980; Carter et al., 1993; Koluvek et al., 1993). Drip irrigation has been shown to result in much lower off-field transport of sediment than sprinkler and furrow methods (McHugh et al., 2008), and was introduced to California in the early 1960s. Large scale shifts in agricultural practices toward drip irrigation was contemporary with the decrease in suspended sediment 
concentration-discharge relationship observed for fine and sand sized sediment in the lower Salinas River. Although drip irrigation was used for only 14\% irrigated land coverage by 1993, over the next 17 years land area under drip irrigation quadrupled, replacing sprinkler and furrow methods as the primary irrigation practice in the Salinas Valley. This change in irrigation technology may be the dominant driver of not only the decreasing fine and sand sediment production trend found from 1967-2011, but also the timing of the departure from the hydrologic and climatic controls that Gray et al. (2015a) found for fine sediment in the late 1990s to early 2000s.

Drip irrigation has largely replaced older methods of irrigation for certain crops throughout California and other semi-arid or dry-summer climatic regions over recent decades, primarily due to increases in yields of high value row crops such as tomatoes (Hanson and May, 2004; Mark Lundy, University of California Cooperative Extension, personal communication). Widespread adoption of drip irrigation for such crops could have the unintended side-effect of reducing the entrainment of agricultural sediments into fluvial systems in these regions, which may have beneficial water quality consequences. Fluvial sediments are the greatest single impairment of rivers and streams in California, many other parts of the U.S. and the world (USEPA, 2014). Furthermore, agricultural sediments are often exposed to surface reactive nutrients such as phosphates, and multiple pesticides, many of which are hydrophobic and primarily transported off-site in association with fine sediments (Weston et al., 2004). Although winter season erosion remains an issue on such fields in single cropped areas, the time period between pesticide application and off-field is much longer for sediments eroded during the winter, perhaps decreasing winter off-field sediment associated pesticide fluxes. Thus, increases in drip irrigation use could yield a potential benefit in reducing the delivery of agricultural 
sediment to water bodies, particularly during the times when these sediments are most contaminated.

\section{Conclusions}

Neither wildfire effective burn area nor its coincidence with large rainfall/runoff events were found to have consistently identifiable effects on suspended sediment flux from the Salinas River from 1967 to 2011. The prevailing negative trends in suspended sediment concentration observed over this period ran directly contrary to the positive trend in basin wide effective burn area. Thus, other factors acting to decrease sediment supply and/or transport through the basin were sufficient to mask the inter-decadal scale effects of wildfire. The wildfire induced sediment signal itself was also possibly dampened due to the issues of low proportional burn areas for any given year, which were generally mosaics of even smaller fires in headland catchments with sediment transport pathways that traversing a mainstem valley floor likely prone to deposition and resuspension processes operating over a wide range of time scales.

Antecedent basin conditions described by the hydrologic history of the basin were previously identified as significant factors affecting much of the decadal to inter-decadal scale pattern in suspended sediment behavior in the Salinas River. However, changes in land use, particularly a shift to less erosive drip irrigation techniques may have been responsible in part for decreasing suspended sediment concentration, particularly for the fine fraction. Process based field inquiry would be required to corroborate these stochastic findings, which highlight the often complicated host of controls operating on suspended sediment production dynamics in semi-arid, developed watersheds. 


\section{Acknowledgements}

This research was funded largely by the National Science Foundation under award No. 0628385. Additional support for the lead author was provided by an Ernest E. Hill Fellowship, a William and Linda Sullivan Scholarship, and support from the Hydrologic Sciences Graduate Group at the University of California, Davis. This project was also supported by USDA National Institute of Food and Agriculture, Hatch projects number \#CA-D-LAW-7034-H and CA-R-ENS-5120-H. Any opinions, findings and conclusions or recommendations expressed in this material are those of the authors and do not necessarily reflect the views of the National Science Foundation. We thank Peter Barnes, Sarah Greve, Duyen Ho, Olivia Oseguera, Larissa Salaki, and the Elkhorn Slough National Estuarine Research Reserve for laboratory and field assistance.

\section{References}

Abaci O, Papanicolaou A. 2009. Long-term effects of management practices on water-driven soil erosion in an intense agricultural sub-watershed: monitoring and modelling. Hydrol. Process., 23: $2818-2837$.

Abraham CE. 1969. Suspended sediment discharges in streams. US Army Corps of Engineers. Institute for Water Resources. Technical Paper 19.

Andrews ED, Antweiler RC, Neiman PJ, Ralph FM. 2004. Influence of ENSO on flood frequency along the California coast. J. Clim., 17: 337-348. DOI: 10.1175/15200442(2004)017<0337:ioeoff>2.0.co;2. 
Beschta RL. 1978. Long-term patterns of sediment production following road construction and logging in the Oregon Coast Range. Water Resour. Res., 14: 1011-1016. DOI: 10.1029/WR014i006p01011.

Brewer WH, Farquhar FP. 1966. Up and Down California in 1860-1864. University of California Press, Berkeley, CA.

Brown and Caldwell. 2015. State of the Salinas River groundwater basin report. prepared for the Monterey County Water Resources Agency. Salinas, CA. 239pp.

Brush, GS. 1989. Rates and patterns of estuarine sediment accumulation. Limnolqy and Oceanography, 34: 1235-1246.

Cal Fire. 2015. California Department of Forestry and Fire Protection Fire Resource Assessment Program. Geospatial and temporal wildfire data. http://frap.cdf.ca.gov/data/frapgisdata-swfireperimeters_download.php. (last accessed 9/4/2015).

Cannon SH. 2001. Debris-flow generation from recently burned watersheds. Environmental \& Engineering Geoscience, 7: 321-341. DOI: 10.2113/gseegeosci.7.4.321.

Carter DL, Brockway CE, Tanji KK. 1993. Controlling erosion and sediment loss from furrowirrigated cropland. Journal of Irrigation and Drainage Engineering-Asce, 119: 975-988. DOI: 10.1061/(asce)0733-9437(1993)119:6(975).

Cerdà A. 1998. Post-fire dynamics of erosional processes under Mediterranean climatic conditions. Z. Geomorphol., 42: 373-398.

Cerdà A, Lasanta T. 2005. Long-term erosional responses after fire in the Central Spanish Pyrenees: 1. Water and sediment yield. Catena, 60: 59-80. DOI: http://dx.doi.org/10.1016/j.catena.2004.09.006. 
Cleveland WS. 1979. Robust locally weighted regression and smoothing scatterplots. J. Am.

Stat. Assoc., 74: 829-836.

Crespí J, Brown AK. 2001. A description of distant roads: original journals of the first expedition into California, 1769-1770. San Diego State University Press. San Diego, CA.

DeBano LF. 2000. The role of fire and soil heating on water repellency in wildland environments: a review. J. Hydrol., 231-232: 195-206. DOI: http://dx.doi.org/10.1016/S0022-1694(00)00194-3.

Debano LF, Krammes JS. 1966. Water repellent soils and their relation to wildfire temperatures. International Association of Scientific Hydrology. Bulletin, 11: 14-19. DOI: $10.1080 / 02626666609493457$.

Espey WH. 1969. Urban effects on the unit hydrograph. (Moore, W. L. and Morgan, C. W., eds.), Effects of watershed changes on streamflow University of Texas Press, Austin, 215228.

Estrany J, Garcia C, Batalla RJ. 2009. Suspended sediment transport in a small Mediterranean agricultural catchment. Earth Surf. Process. Landf., 34: 929-940. DOI: 10.1002/esp.1777.

Farnsworth KL, Milliman JD. 2003. Effects of climatic and anthropogenic change on small mountainous rivers: the Salinas River example. Glob. Planet. Change, 39: 53-64. DOI: $10.1016 / \mathrm{s} 0921-8181(03) 00017-1$.

Fisher AB. 1945. The Salinas, Upside Down River. Farrar \& Rinehart Incorporated.

Florsheim JL, Keller EA, Best DW. 1991. Fluvial sediment transport in response to moderate storm flows following chaparral wildfire, Ventura County, southern California. Geol. Soc. Am. Bull., 103: 504-511. DOI: 10.1130/0016-7606(1991)103<0504:fstirt>2.3.co;2. 
Florsheim JL, Pellerin BA, Oh NH, Ohara N, Bachand PAM, Bachand SM, Bergamaschi BA, Hernes PJ, Kavvas ML. 2011. From deposition to erosion: Spatial and temporal variability of sediment sources, storage, and transport in a small agricultural watershed. Geomorphology, 132: 272-286. DOI: 10.1016/j.geomorph.2011.04.037.

Freeman JE. 1855. Copy of field notes of surveys of township and range lines executed by James E. Freeman, Deputy Surveyor. General Land Office, U.S. Department of the Interior, Bureau of Land Management Rectangular Survey, California, Vol. 257-2 and 257-3, pp. 19-88.

Gabet EJ. 2003. Post-fire thin debris flows: sediment transport and numerical modelling. Earth Surf. Process. Landf., 28: 1341-1348. DOI: 10.1002/esp.590.

Gao P, Pasternack GB. 2007. Dynamics of suspended sediment transport at field-scale drain channels of irrigation-dominated watersheds in the Sonoran Desert, southeastern California. Hydrol. Process., 21: 2081-2092. DOI: 10.1002/hyp.6398.

Gao P, Nearing MA, Commons M. 2013. Suspended sediment transport at the instantaneous and event time scales in semiarid watersheds of southeastern Arizona, USA. Water Resour. Res., 49: 6857-6870. DOI: 10.1002/wrcr.20549.

Gray AB, Pasternack GB, Watson EB. 2010. Hydrogen peroxide treatment effects on the particle size distribution of alluvial and marsh sediments. Holocene, 20: 293-301. DOI: $10.1177 / 0959683609350390$.

Gray AB, Warrick JA, Pasternack GB, Watson EB, Goñi MA. 2014. Suspended sediment behavior in a coastal dry-summer subtropical catchment: Effects of hydrologic preconditions. Geomorphology, 214: 485-501. DOI: http://dx.doi.org/10.1016/j.geomorph.2014.03.009.

Gray AB, Pasternack GB, Watson EB, Warrick JA, Goni MA. 2015a. The effect of El Nino Southern Oscillation cycles on the decadal scale suspended sediment behavior of a coastal 
dry-summer subtropical catchment. Earth Surf. Process. Landf., 40: 272-284. DOI: 10.1002/esp.3627.

Gray AB, Pasternack GB, Watson EB, Warrick JA, Goni MA. 2015b. Effects of antecedent hydrologic conditions, time dependence, and climate cycles on the suspended sediment load of the Salinas River, California. J. Hydrol., 525: 632-649. DOI: 10.1016/j.jhydrol.2015.04.025.

Griffin D, Anchukaitis, KJ. 2014. How unusual is the 2012-2014 California drought?

Geophysical Research Letters 41: 9017-9023, doi:10.1002/2014GL062433.

Guinn JM. 1890. Exceptional years: a history of California floods and drought. Historical Society of Southern California (1) 5: 33-39.

Hanes TL. 1971. Succession after Fire in the Chaparral of Southern California. Ecol. Monogr., 41: 27-52. DOI: $10.2307 / 1942434$.

Hanson B and May D. 2004. Effects of subsurface drip irrigation on processing tomato yield, water table depth, soil salinity, and profitability. Ag. Water Manag. 68: 1-17.

Helsel DR, Hirsch RM. 2002. Statistical Methods in water resources - hydrologic analysis and interpretation. In: U.S. Geological Survey Techniques of Water-Resources Investigations, pp: 510.

Hill PS, Nowell ARM, Jumars PA. 1988. Flume evaluation of the relationship between suspended sediment concentration and excess boundary shear-stress. J. Geophys. Res.Oceans, 93: 12499-12509. DOI: 10.1029/JC093iC10p12499.

Hollis GE. 1975. The effect of urbanization on floods of different recurrence interval. Water Resour. Res., 11: 431-435. DOI: 10.1029/WR011i003p00431. 
Horowitz AJ. 2003. An evaluation of sediment rating curves for estimating suspended sediment concentrations for subsequent flux calculations. Hydrol. Process., 17: 3387-3409. DOI: 10.1002/hyp.1299.

Hubbert KR, Wohlgemuth PM, Beyers JL, Narog MG, Gerrard R. 2012. Post-fire soil water repellency, hydrologic response, and sediment yield compared between grass-converted and chaparral watersheds. Fire Ecology, 8(2): 143-162.

Inbar M, Tamir M, Wittenberg L. 1998. Runoff and erosion processes after a forest fire in Mount Carmel, a Mediterranean area. Geomorphology, 24: 17-33. DOI: 10.1016/s0169$555 x(97) 00098-6$.

Inman DL, Jenkins SA. 1999. Climate change and the episodicity of sediment flux of small California rivers. J. Geol., 107: 251-270.

Jackson M, Roering JJ. 2009. Post-fire geomorphic response in steep, forested landscapes: Oregon Coast Range, USA. Quat. Sci. Rev., 28: 1131-1146. DOI: 10.1016/j.quascirev.2008.05.003.

Kahn H, Brush GS. 1994. Nutrient and metal accumulation in a freshwater tidal marsh. Estuaries 17: $345-360$.

Keller EA, Valentine DW, Gibbs DR. 1997. Hydrological response of small watersheds following the southern California painted cave fire of June 1990. Hydrol. Process., 11: 401414. DOI: 10.1002/(SICI)1099-1085(19970330)11:4<401::AID-HYP447>3.0.CO;2-P.

Keeley JE, Fotheringham CJ. 2003. Impact of past, present, and future fire regimes on North American Meditteranean shrublands. in Fire and climatic change in temperate ecosystems of the western Americas. Veblen TT, Baker WL, Montenegro G, Swetnam TW, Editors. Springer-Verlag, New York. 218-262. 
Keeley JE, Zedler PH. 2009. Large, high-intensity fire events in southern California shrublands: debunking the fine-grain age patch model. Ecol. Appl., 19: 69-94. DOI: 10.1890/08-0281.1.

Koluvek PK, Tanji KK, Trout TJ. 1993. Overview of soil erosion from irrigation. Journal of Irrigation and Drainage Engineering 119: 929-946.

Lamb MP, Scheingross JS, Amidon WH, Swanson E, Limaye A. A model for fire-induced sediment yield by dry ravel in steep landscapes. Journal of Geophysical Research: Earth Surface 2011; 116: F03006.

Lana-Renault N, Regues D, Marti-Bono C, Begueria S, Latron J, Nadal E, Serrano P, GarciaRuiz JM. 2007. Temporal variability in the relationships between precipitation, discharge and suspended sediment concentration in a small Mediterranean mountain catchment. Nord. Hydrol., 38: 139-150. DOI: 10.2166/nh.2007.003.

Lanman CW., Lundquist K, Perryman H, Asarian JE, Dolman B, Lanman RB, Pollock MM. 2013. The historical range of beaver (Castor canadensis) in coastal California: an updated review of the evidence. California Fish and Game, 99 (4): 193-331.

Lapham MH, Heileman WH. 1901. Soil survey of the lower Salinas River, California. U.S. Department of Agriculture, Bureau of Soils. p. 481-519.

Lavé J, Burbank D. 2004. Denudation processes and rates in the Transverse Ranges, southern California: Erosional response of a transitional landscape to external and anthropogenic forcing. J. Geophys. Res.-Earth Surf., 109. DOI: F01006.10.1029/2003jf000023.

Lenzi MA, Marchi L. 2000. Suspended sediment load during floods in a small stream of the Dolomites (northeastern Italy). Catena, 39: 267-282. 
López-Tarazón, Batalla RJ, Vericat D. 2011. In-channel sediment storage in a highly erodible catchment: the River Isabena (Ebro Basin, Southern Pyrenees). Z. Geomorphol., 55: 365382. DOI: $10.1127 / 0372-8854 / 2011 / 0045$.

Lynch, H.B. 1931. Rainfall and stream run-off in southern California since 1769. The Metropolitan Water District of southern California, Los Angeles, CA.

Malmon DV, Reneau SL, Katzman D, Lavine A, Lyman J. 2007. Suspended sediment transport in an ephemeral stream following wildfire. Journal of Geophysical Research: Earth Surface, 112: n/a-n/a. DOI: 10.1029/2005JF000459.

Margolin M. 1978. The Ohlone Way: Indian Life in the San Francisco-Monterey Bay Area. Heyday, Berkeley, CA.

McHugh AD, Bhattarai S, Lotz G, Midmore DJ. 2008. Effects of subsurface drip irrigation rates and furrow irrigation for cotton grown on a vertisol on off-site movement of sediments, nutrients and pesticides. Agron. Sustain. Dev., 28: 507-519. DOI: 10.1051/agro:2008034.

Mensing SA, Michaelsen J, Byrne R. 1999. A 560-Year Record of Santa Ana Fires Reconstructed from Charcoal Deposited in the Santa Barbara Basin, California. Quat. Res., 51: 295-305. DOI: http://dx.doi.org/10.1006/qres.1999.2035.

Milliman JD, Meade RH. 1983. World-wide delivery of river sediment to the oceans. J. Geol., 91: 1-21.

Minear JT. 2010. The downstream geomorphic effects of dams: A comprehensive and comparative approach. Dissertation submitted to Department of Landscape Architecture and Environmental Planning, University of California, Berkeley. 207 pp.

Minnich RA.1983. Fire mosaics in southern California and northern Baja California. Science, 219(4590): 1287-1294. 
Monterey County. 2015. Monterey County Agricultural Commissioner's Office Crop Reports http://www.co.monterey.ca.us/government/departments-a-h/agriculturalcommissioner/forms-publications/crop-reports-economic-contributions (last accessed 9/4/2015).

Monterey County. 2015b. Monterey County Summary Ground Water Reports of the Monterey Water Resources Agency. http://www.mcwra.co.monterey.ca.us/groundwater_extractionsummary/groundwater-extractioe_summary.php (last accessed 9/4/2015).

Moody JA, Martin DA, Haire SL, Kinner DA. 2008. Linking runoff response to burn severity after a wildfire. Hydrol. Process., 22: 2063-2074. DOI: 10.1002/hyp.6806.

Morehead MD, Syvitski JP, Hutton EWH, Peckham SD. 2003. Modeling the temporal variability in the flux of sediment from ungauged river basins. Glob. Planet. Change, 39: 95-110. DOI: $10.1016 / \mathrm{s} 0921-8181(03) 00019-5$.

Moritz MA. 2003. Spatiotemporal analysis of controls on shrubland fire regimes: Age dependency and fire hazard. Ecology, 84: 351-361. DOI: 10.1890/00129658(2003)084[0351:saocos]2.0.co;2.

PAST Consultants LLC. 2010. Historic context statement for agricultural resources in the north county planning area, Monterey County.

Pasternack GB, Brush GS, Hilgartner WB. 2001. Impact of historic land-use change on sediment delivery to a Chesapeake Bay subestuarine delta. Earth Surf. Process. Landf., 26: 409-427. DOI: $10.1002 /$ esp.189.

Piegay H, Walling DE, Landon N, He QP, Liebault F, Petiot R. 2004. Contemporary changes in sediment yield in an alpine mountain basin due to afforestation (the upper Drome in France). Catena, 55: 183-212. DOI: 10.1016/s0341-8162(03)00118-8. 
Planert M, Williams JS. 1995. Ground water atlas of the United States - California, Nevada. U.S. Geological Survey, Publication HA 730-B, Reston, VA.

Porter GA, Ehrlich R, Osborne RH, Combellick RA. 1979. Sources and nonsources of beach sand along southern Monterey Bay, California - Fourier shape analysis. J. Sed. Pet., 49(3): 727-732.

Pyne ST, Andrews PL, Laven RD. 1996. Introduction to Wildland Fire. New York: Wiley. 769 pp.

Rice RM, 1982. Sedimentation in the chaparral: how do you handle unusual event? in Sediment Budgets and Routing in Forested Drainage Basins. Rep. USDA-FS, Pacific Northwest Forest and Range Experiment Station. PNW-141: 39-49.

Rosenberg LI, Joseph JC. 2009. Map of the Rinconada and Reliz Fault Zones, Salinas River Valley, California: U.S. Geological Survey Scientific Investigations Map 3059, scale 1:250,000 with pamphlet, http://pubs.usgs.gov/sim/3059/.

Rouse H. 1937. Modern conceptions of the mechanics of fluid turbulence. Transactions of the American Society of Civil Engineers 102: 463-541.

Sass O, Haas F, Schimmer C, Heel M, Bremer M, StÖGer F, Wetzel K-F. 2012. Impact of forest fires on geomorphic processes in the Tyrolean limestone Alps. Geografiska Annaler: Series A, Physical Geography, 94: 117-133. DOI: 10.1111/j.1468-0459.2012.00452.x.

Shakesby RA, Doerr SH. 2006. Wildfire as a hydrological and geomorphological agent. EarthScience Reviews, 74: 269-307. DOI: 10.1016/j.earscirev.2005.10.006.

Smith-Lintner CA. 2007. Becoming Californio: Archaeology of communities, animals, and identity in colonial California. Ph.D. Dissertation, University of California at Berkeley. 
Staley DM, Wasklewicz TA, Kean JW. Characterizing the primary material sources and dominant erosional processes for post-fire debris-flow initiation in a headwater basin using multi-temporal terrestrial laser scanning data. Geomorphology 2014; 214: 324-338.

Swanson FJ. 1981. Fire and geomorphic processes, in Proceedings of the Conference on Fire Regimes and Ecosystem Properties, December 11-15, 1978, Honolulu, Hawaii, USDA Forest Service Publication WO-26: 401-420.

Syvitski JP, Morehead MD, Bahr DB, Mulder T. 2000. Estimating fluvial sediment transport: The rating parameters. Water Resour. Res., 36: 2747-2760. DOI: 10.1029/2000wr900133. Syvitski JPM, Vörösmarty CJ, Kettner AJ, Green P. 2005. Impact of Humans on the Flux of Terrestrial Sediment to the Global Coastal Ocean. Science, 308: 376-380. DOI: 10.1126/science. 1109454.

Syvitski JPM, Milliman JD. 2007. Geology, geography, and humans battle for dominance over the delivery of fluvial sediment to the coastal ocean. J. Geol., 115: 1-19. DOI: $10.1086 / 509246$.

Tananaev, NI. 2013. Applying regression analysis to calculating suspended sediment runoff: specific features of the method. Water Resources, 40: 585-592.

Tanji KK, Biggar JW, Miller RJ, Pritt WO, Horner GL. 1980. Irrigation tailwater management. Final report to U.S. Environmental Protection Agency. University of California, Davis. Water Science and Engineering Paper No. 4020.

Tanji KK, Singer M, Biggar J, Whittig L, Henderson D. 1983. Nonpoint sediment production in the Colusa Basin Drainage Area, California. Final Report to the EPA on Grant No. 805462 and No. 807169. University of California, Davis. Department of Land, Air and Water Resources. Robert S. Kerr Environmental Research Lab. 112 pp. 
Thompson JG, Reynolds R. 2002. Cultural evolution and water management in the Salinas River Valley. J. Am. Water Resour. Assoc., 38: 1661-1677. DOI: 10.1111/j.17521688.2002.tb04372.x.

Tomer MD, Wilson CG, Moorman TB, Cole KJ, Heer D, Isenhart TM. 2010. Source-pathway separation of multiple contaminants during a rainfall-runoff event in an artificially drained agricultural watershed. J. Environ. Qual., 39: 882-895. DOI: 10.2134/jeq2009.0289.

Trimble SW. 1997. Contribution of stream channel erosion to sediment yield from an urbanizing watershed. Science, 278: 1442-1444. DOI: 10.1126/science.278.5342.1442.

U.S. Environmental Protection Agency (USEPA). 2014. California Water Quality Assessment Report. http://iaspub.epa.gov/tmdl_waters10/attains_state.control?p_state=CA\#causes. Last accessed 10/9/2015.

U.S. Geological Survey National Water Information System (USGS NWIS). 2015 http://waterdata.usgs.gov/nwis/sw (last accessed: 07/2015).

Vorosmarty CJ, Meybeck M, Fekete B, Sharma K, Green P, Syvitski JPM. 2003. Anthropogenic sediment retention: major global impact from registered river impoundments. Glob. Planet. Change, 39: 169-190. DOI: 10.1016/s0921-8181(03)00023-7.

Walling DE. 1977. Assessing accuracy of suspended sediment rating curves for a small basin. Water Resour. Res., 13: 530-538.

Walling DE. 2006. Human impact on land-ocean sediment transfer by the world's rivers.

Geomorphology, 79: 192-216. DOI: 10.1016/j.geomorph.2006.06.019.

Walling DE, Fang D. 2003. Recent trends in the suspended sediment loads of the world's rivers. Glob. Planet. Change, 39: 111-126. DOI: 10.1016/s091-8181(03)00020-1. 
Walling DE, Webb, BW. 1988. The reliability of rating curve estimates of suspended sediment yield: some further comments. Sediment Budgets: Proceedings of the Porto Alegre Symposium, December 1988. IAHS Publ. no. 174: 337-350.

Warrick JA. 2014. Trend analyses with river sediment rating curves. Hydrol. Process.: n/a-n/a. DOI: 10.1002/hyp.10198.

Warrick JA, Rubin DM. 2007. Suspended-sediment rating curve response to urbanization and wildfire, Santa Ana River, California. J. Geophys. Res.-Earth Surf., 112. DOI: F02018.10.1029/2006jf000662.

Warrick JA, Hatten JA, Pasternack GB, Gray AB, Goni MA, Wheatcroft RA. 2012. The effects of wildfire on the sediment yield of a coastal California watershed. Geol. Soc. Am. Bull., 124: 1130-1146. DOI: 10.1130/b30451.1.

Warrick JA, Madej MA, Goni MA, Wheatcroft RA. 2013. Trends in the suspended-sediment yields of coastal rivers of northern California, 1955-2010. J. Hydrol., 489: 108-123. DOI: 10.1016/j.jhydrol.2013.02.041.

Weston NB. 2014. Declining sediments and rising seas: an unfortunate convergence for tidal wetlands. Estuaries and Coasts 37(1): 1-23.

Weston DP, You J, Lydy MJ. 2004. Distribution and toxicity of sediment-associated pesticides in agriculture-dominated water bodies of California's Central Valley. 38: 2752-2759.

Willis CM, Griggs GB. 2003. Reductions in fluvial sediment discharge by coastal dams in California and implications for beach sustainability. J. Geol., 111: 167-182. DOI: $10.1086 / 345922$. 
Wilson CG, Kuhnle RA, Dabney SM, Lerch RN, Huang CH, King KW, Livingston SJ. 2014. Fine sediment sources in Conservation Effects Assessment Project watersheds. Journal of Soil and Water Conservation, 69: 402-413. DOI: 10.2489/jswc.69.5.402.

Wohlgemuth PM, Hubbert KR. 2008. Properties and sediment fluxes in chaparral steeplands, southern California. in USDA Forest Service General Technical Report. PSW-GTR189.2008: 115-122.

Wolman MG. 1967. A cycle of sedimentation and erosion in urban river channels. Geografiska Annaler, 49A: 385-395.

Wolman MG, Schick AP. 1967. Effects of construction on fluvial sediment, urban and suburban areas of Maryland. Water Resour. Res., 3: 451-464. DOI: 10.1029/WR003i002p00451. 


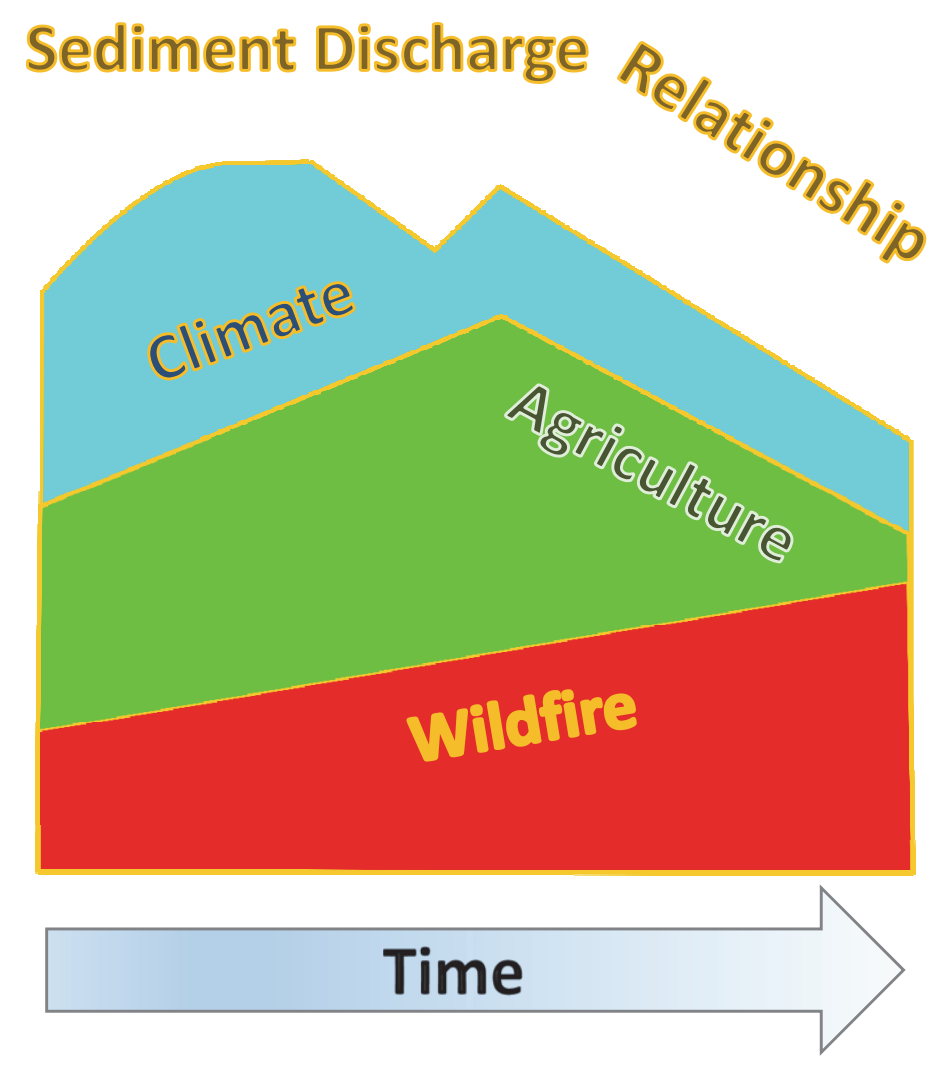

